\title{
Analisis Kedudukan dan Status Hukum Ketetapan MPR RI Berdasarkan Undang-Undang Nomor 12 Tahun 2011 tentang Pembentukan Peraturan Perundang-Undangan
}

Titik Triwulan Tutik

Fakultas Syari' ah IAIN Sunan Ampel Surabaya

Jl. Jend. A. Yani 117 Surabaya

tt_titik@yahoo.com

\section{Abstract}

This research discusses: First, the juridical ratio of the position of People's Consultative Assembly's adjudication which re-enters the regulations of law hierarchy. Second, the position and legal status of the People's Consultative Assembly's adjudication based on Law Number 12 of 2011 on the Formulation of Regulations of Law compared with the position and legal status of the previous People's Consultative Assembly's adjudications. The research method used in this research was normative-juridical method. The approach used was historical and statute approaches. The research finding shows that: First, the position of People's Consultative Assembly's adjudication in the regulations of law hierarchy is conditio sine quanon. Second, the legal status of the People's Consultative Assembly's adjudication based on Law Number 12 of 2011 is different from the People's Consultative Assembly's adjudications prior to the amendment of Constitution 1945 of the Republic of Indonesia. This is in regards with the fact that the People's Consultative Assembly after the amendment of Constitution 1945 has the position as state high institution.

Key words: Adjudication of people's consultative assembly, bierarchy, regulations of law

\section{Abstrak}

Penelitian ini mengangkat permasalahan: pertama, rasio-yuridis kedudukan Ketetapan MPR masuk kembali dalam hierarki peraturan perundang-undangan. Kedua, kedudukan dan status hukum Ketetapan MPR berdasarkan Undang-Undang Nomor 12 Tahun 2011 tentang Pembentukan Peraturan Perundang-Undangan dengan kedudukan dan status hukum Ketetapan MPR sebelumnya. Metode penelitian yang digunakan dalam penelitian ini adalah yuridis normatif. Pendekatan yang dipergunakan dalam penelitian adalah pendekatan historis (historical approach) dan pendekatan perundangundangan (statute approach). Hasil penelitian menunjukkan bahwa: pertama, kedudukan Ketetapan MPR dalam hierarki peraturan perundang-undangan merupakan conditio sine quanon. Kedua, status hukum dari Ketetapan MPR berdasarkan Undang-Undang Nomor 12 Tahun 2011 berbeda dengan Ketetapan MPR sebelum perubahan UUDNRI 1945. Hal ini mengingat bahwa MPR setelah perubahan UUD 1945 berkedudukan sebagai lembaga tinggi negara sebagai mana lembaga tinggi negara lainnya.

Kata Kunci : Tap MPR, hierarki, peraturan perundang-undangan 


\section{Pendahuluan}

Reformasi hukum yang terjadi sejak 1998 dilembagakan melalui, antara lain, pranata perubahan UUD 1945 (baca: UUD NRI 1945). Semangat UUD NRI 1945 adalah mendorong terbangunnya struktur ketatanegaraan yang lebih demokratis. Perubahan UUD 1945 sejak reformasi telah dilakukan sebanyak empat kali, yaitu: pertama, perubahan pertama disahkan pada 19 Oktober 1999; kedua, perubahan kedua disahkan pada 18 Agustus 2000; ketiga, perubahan ketiga disahkan pada 10 November 2001; keempat, perubahan keempat disahkan pada 10 Agustus $2002 .{ }^{1}$

Perubahan UUD 1945 melahirkan bangunan kelembagaan negara yang satu sama lain dalam posisi setara dengan saling melakukan checks and balances ${ }^{2}$, mewujudkan supremasi hukum dan keadilan serta menjamin dan melindungi hak asasi manusia. Kesetaraan dan ketersediaan saling kontrol inilah prinsip dari sebuah negara demokrasi ${ }^{3}$ dan negara hukum ${ }^{4}$.

Implikasi perubahan UUD 1945 membawa dampak sangat luas terhadap semua lembaga negara. Pada salah satu sisi, ada lembaga negara yang mendapat proporsi baru yaitu dengan bertambahnya kewenangan secara signifikan di dalam konstitusi. Sementara di sisi lain, ada pula lembaga negara yang mengalami pengurangan kewenangannya dibandingkan dengan sebelum dilakukan perubahan ${ }^{5}$. Tidak hanya itu, ada pula lembaga negara yang dihilangkan karena dinilai tidak relevan lagi bagi kebutuhan penyelenggaraan negara ke depan ${ }^{6}$. Di antara implikasi perubahan UUD 1945, lembaga perwakilan rakyat termasuk yang paling tampak mengalami perubahan dan penataan. Salah satunya adalah perubahan kedudukan dan fungsi Majelis Permusyawaratan Rakyat (MPR).

${ }^{1}$ Titik Triwulan Tutik, Konstruksi Hukum Tata Negara Indonesia Pasca Amandemen UUD 1945, Kencana Prenada Media Group, Jakarta, 2010, hlm. 359.

${ }^{2}$ Ayudya Widawati, "Seleksi Hakim Agung 2008, Mencari Hakim Agung yang Profesional, Berkualitas, Berintegrasi, Akuntabel dan Transparan dalam Rangka Menegakkan Prinsip Checks and Balances Kekuasaan Kehakiman di Indonesia", dalam Jurnal Teropong, Vol. VII No. 1, 2008, hlm. 28. Lihat juga Bruce Ackerman, "The New Separation Powers", dalam The Harvard Law Review, Vol. 113, 2000, hlm. 113.

${ }^{3}$ Martha Pigome, "Implementasi Prinsip Demokrasi dan Nomokrasi dalam Struktur Ketatanegaraan RI Pasca Amandemen UUD 1945”, artikel dalam Jurnal Dinamika Hukum, Vol. 11 No. 2, 2011, hlm. 324.

${ }^{4}$ Denny Indrayana, "Negara Hukum Indonesia Pasca Soeharto: Transisi Menuju Demokrasi vs Korupsi”, artikel dalam Jurnal Konstitusi, Vol. 1 No. 1, 2004, hlm. 101. Lihat juga Bambang Heryanto, "Refleksi Politik Hukum Pelanggaran Hak Asasi Manusia di Indonesia”, artikel dalam Majalab Hukum Yuridika, Vol. 17 No. 4, 2002, hlm. 334.

${ }^{5}$ Kuntana Magnar, "Kedudukan, Tugas, Fungsi dan Kewenangan Lembaga-Lembaga Negara di Indonesia", artikel dalam Jurnal Imu Hukum Litigasi, Vol. 1 No. 2 Th. 2007, hlm. 25. Lihat juga Nurul Chotidjah, "Dinamika Implementasi Kewenangan Mahkamah Agung dan Komisi Yudisial setelah Amandemen Undang-Undang Dasar 1945", artikel dalam Jurnal Imu Hukum Litigasi, Vol. IX No. 3, 2008, hlm. 300. Lihat juga Heru Susetyo, "Reformasi Konstitusi dari Aspek Lembaga Negara", artikel dalam Jurnal Legislasi Indonesia, Vol. 7 No. 1, 2007, hlm. 5.

${ }^{6}$ R. Agung Laksono, "Dewan Perwakilan Rakyat Republik Indonersia Pasca Perubahan Undang-Undang Dasar Negara Republik Indonesia Tahun 1945”, artikel dalam Jurnal Majelis, Vol. 1 No. 1, 2009, hlm. 48. 
Perubahan UUD 1945 memposisikan MPR tidak lagi berkedudukan sebagai lembaga tertinggi negara dan pemegang kedaulatan rakyat tertinggi ${ }^{7}$. Hal ini berimplikasi pada kewenangan MPR yang dahulu memiliki kedudukan strategis, yaitu menetapkan UUD, menetapkan GBHN, memilih presiden dan wakil presiden melalui amandemen kewenangannya menjadi: (1) mengubah dan menetapkan UUD; (2) melantik presiden dan/atau wakil presiden; (3) memberhentikan presiden dan/ atau wakil presiden dalam masa jabatannya menurut UUD 1945. Akibat dari ketentuan UUD NRI 1945, keberadaan MPR dalam sistem ketatanegaraan menjadi tawar dan mandul, termasuk produk hukum yang dihasilkan seperti Ketetapan MPR. Bahkan melalui Undang-Undang Nomor 10 Tahun 2004 tentang Pembentukan Peraturan Perundang-undangan - telah mencabut produk hukum MPR yang berupa Ketetapan MPR (Tap MPR) dalam hierarki peraturan perundang-undangan. Kenyataan demikian semakin memarginalkan kedudukan dan status hukum dari Ketetapan MPR, padahal berdasarkan Tap MPR No. 1/MPR/2003 tentang Peninjauan terhadap Materi dan Status Hukum Hukum Tap MPRS dan Tap MPR tahun 1960-2002 masih memberikan dasar adanya keberlakuan bagi beberapa Tap MPR/MPRS karena masih dianggap relevan dan keberadaan masih dibutuhkan.

Kedudukan dan status hukum Tap MPR kembali memperoleh angin segar setelah diundangkannya Undang-Undang Nomor 12 Tahun 2011 tentang Pembentukan Peraturan Perundang-Undangan yang memberikan landasan hukum bagi keberlakuan kembali Tap MPR dalam aturan hukum di Indonesia. Meski demikian, keberadaan Tap MPR menurut ketentuan hukum ini masih debatable. Hal ini mengingat bahwa berdasarkan UUD NRI 1945 kedudukan MPR tidak lagi sebagai lembaga tertinggi negara sebagaimana menurut UUD 1945 (UUD 1945 sebelum perubahan), tetapi hanya sebatas sebagai lembaga tinggi negara sebagaimana lembaga-lembaga tinggi negara yang lain. Hal ini menimbulkan masalah hukum menyangkut kedudukan dan status hukum dari Tap MPR itu sendiri, khususnya dalam hierarki peraturan perundang-undangan.

\section{Rumusan Masalah}

Berdasarkan latar belakang permasalahan tersebut, maka penelitian ini bermaksud menganalisis kedudukan dan status hukum Ketetapan MPR berdasarkan 
Undang-Undang Nomor 12 Tahun 2011. Permasalahan yang hendak diteliti: pertama, bagaimanakah rasio-yuridis kedudukan Ketetapan MPR masuk kembali dalam hierarki peraturan perundang-undangan? kedua, tidak samakah kedudukan dan status hukum Ketetapan MPR berdasarkan Undang-Undang Nomor 12 Tahun 2011 dengan kedudukan dan status hukum Ketetapan MPR sebelumnya?

\section{Tujuan Penelitian}

Penelitian ini bertujuan untuk mengetahui: pertama, rasio-yuridis kedudukan Ketetapan MPR masuk kembali dalam hierarki peraturan perundang-undangan. Kedua, kedudukan dan status hukum Ketetapan MPR berdasarkan Undang-Undang Nomor 12 Tahun 2011 dengan kedudukan dan status hukum Ketetapan MPR sebelumnya.

\section{Metode Penelitian}

Jenis penelitian ini merupakan penelitian hukum normatif atau dogmatik ${ }^{8}$, yang ditujukan untuk menemukan dan merumuskan argumentasi hukum, melalui analisis terhadap pokok permasalahan. Pendekatan yang digunakan dalam penelitian ini ada dua, yaitu pendekatan historis (historical approach) dan pendekatan perundang-undangan (statute approach). ${ }^{9}$ Pengumpulan data dilakukan dengan menghimpun bahan-bahan hukum primer dan sekunder yang terkait topik penelitian. Bahan hukum primer dipelajari dan diidentifikasi, menggunanakan metode "IRAC", yaitu memilih masalah atau pokok bahasan (Identification of object), menentukan peraturan hukum yang relevan (Rule of Law), menganalisis fakta-fakta dari segi hukum (Analysing the facts), dan menyusun kesimpulan/Conclusion ${ }^{10}$. Bahan hukum sekunder semuanya dicatat dengan menggunakan sistem kartu (card system). Kartu-kartu disusun berdasarkan pokok permasalahan penelitian dan sistematika penulisan yang telah dirumuskan. Hasil penelitian yang diperoleh dari bahan-bahan hukum tersebut di atas dicari hubungannya antar satu dengan lainnya dengan

${ }^{8}$ J. Gijssel dalam Philipus M. Hadjon, "Pengkajian Ilmu Hukum Dogmatik (Normatif)", artikel dalam Jurnal Yuridika, Vol. IX No. 6, 1994, hlm. 43.

${ }^{9}$ Terry Hutchinson, Researching and Writing in Law. Lawbook. Co. Pyrmont-NSW-Sydney, Sydney, 2002, hlm. 29. Lihat juga Peter Mahmud Marzuki, "Jurisprudence As Sui Generis Discipline”, artikel dalam Jurnal Hukum Yuridika, Vol. XVII No. 4, 2002, hlm. 309-310.

${ }^{10}$ Terry Hutchinson, Ibid., hlm. 32 
menggunakan penalaran (analisis) deduktif dan induktif untuk menghasilkan proposisi dan konsep baik berupa definisi, deskripsi, maupun klasifikasi sebagai hasil penelitian. Analisis deduktif dilakukan dengan bertitik tolak dari ketentuan UUD NRI 1945 dan dengan dukungan bahan hukum sekunder termasuk kepustakaan hukum tata negara yang menyangkut kedudukan Ketetapan MPR.

\section{Hasil Penelitian dan Pembahasan}

Philipus M. Hadjon membagi jenis aturan hukum meliputi 3 (tiga) produk hukum utama, yaitu: (1) Undang-Undang Dasar [UUD], (2) Undang-Undang (UU), dan (3) Peraturan. ${ }^{11}$ Dengan klasifikasi tersebut, maka tampak jelas pembentukannya, yaitu; (1) UUD dihasilkan oleh MPR, (2) UU merupakan produk legislasi (DPR bersama Presiden), dan (3) Peraturan yang merupakan produk eksekutif dalam rangka regulasi. Klasifikasi tersebut secara otomatis akan berkaitan dengan materi muatan dan dengan sendirinya menunjukkan hierarki.

Dengan pola rumusan jenis aturan hukum menjadi 3 (tiga) kategori tersebut, maka tanpa menyebut hierarki secara otomatis jenis tersebut telah menunjukkan hierarki. UUD berada pada posisi supremasi sehingga menjadi supremasi UUD disusul undang-undang sebagai instrumen hukum utama karena merupakan produk legislasi dan tempat ketiga adalah peraturan sebagai produk regulasi.

Bagaimana dengan hierarki peraturan perundang-undangan di Indonesia? Kalau kita bandingkan dengan negara lain, tidak ada negara yang merumuskan pola hierarki peraturan perundang-undangan seperti Tap MPRS No. XX/MPRS/ 1966, Tap No. III/MPR/2000 dan Pasal 7 ayat (1) UU No. 10 Tahun 2004, maupun UU No. 12 Tahun 2011.

Dari studi perbandingan konstitusi yang telah dilakukan, tidak ada suatu negara pun dari negara Uni Eropa yang merumuskan bentuk aturan hukum seperti tersebut di atas. Latar belakang pola perumusan yang demikian menurut Philipus M. Hadjon, ialah historis konstitusi negara-negara tersebut dengan pola bottom up dan bukan pola top down. Dengan demikian konstitusi hanya mengkonstatir apa yang dikenal dalam praktek ketatanegaraan dan di sisi lain memungkinkan perkembangan bentuk baru aturan hukum secara konstitusional. ${ }^{12}$

${ }^{11}$ Philipus M. Hadjon, “Analisis Terhadap UU No. 10 Tahun 2004 tentang Pembentukan Peraturan PerundangUndangan", Makalah, disampaikan pada Seminar, hlm. 5.

${ }^{12}$ Ibid., hlm. 6 
Pola hubungan hierarki (hubungan tingkatan) yang digunakan, dan bukan pola enumarisasi (daftar aturan hukum), dapat dipaparkan sebagai berikut. a) Konstitusi Jerman. Dalam Pasal 31 menyatakan bahwa hukum federal mengalahkan hukum negara bagian. Rumusan itu menegaskan, bahwa hukum federal superior terhadap hukum negara bagian. Art 20 III menyatakan kekuasaan legislatif tunduk kepada ketentuan konstitusi, kekuasaan eksekutif, dan kekuasaan kehakiman terikat pada ketentuan undang-undang dan keadilan. Rumusan itu menegaskan, bahwa aturan buatan legislatif superior terhadap aturan buatan eksekutif dan yudisial (melalui rechtsvinding). b) Konstitusi Belanda. Dalam Pasal 94 Grondwet: dalam kerajaan tidak boleh diterapkan ketentuan hukum yang bertentangan ketentuan perjanjian (traktat) yang mengikat. Rumusan itu menunjukkan bahwa traktat superior terhadap hukum nasional; c) Konstitusi Perancis merumuskan hubungan hierarki dengan pola yang lain dibandingkan dengan pola Jerman dan Belanda. Pasal 34 Konstitusi Perancis merumuskan daftar kewenangan legislatif dan residu atau sisa dari daftar itu termasuk kewenangan eksekutif yang diatur dalam bentuk 'reglements'.

Dibandingkan dengan ketentuan aturan hukum sebagaimana layaknya ketatanegaraan negara lain, ketatanegaraan Indonesia memiliki karakter yang berbeda dalam hierarki aturan hukum yang tidak dikenal dalam hierarki peraturan perundang-undangan. Perbedaan tersebut adalah dengan memasukkan produk hukum Ketetapan MPR dalam hierarki peraturan perundang-undangannya.

Ketetapan MPR adalah bentuk produk legislatif yang merupakan keputusan musyawarah MPR, yang ditujukan keluar (dari Majelis) yaitu mengatur tentang garisgaris besar dalam bidang legislatif dan eksekutif. Istilah Ketetapan dalam Tap. MPR/ MPRS sebenarnya tidak ada dalam UUD 1945. Istilah ini diambil MPRS pada sidang Pertama, dari bunyi Pasal 3 UUD 1945 naskah asli ${ }^{13}$, di mana terdapat sumber hukum, bahwa MPR berwenang menetapkan UUD, GBHN dalam arti luas ${ }^{14}$, memilih Presiden dan Wapres dan sebagainya. Kemudian oleh Ketetapan MPRS No. XX/MPRS/1966 dijadikan sebagai salah satu bentuk peraturan perundang-undangan (sumber hukum). ${ }^{15}$

Berkaitan dengan wewenang MPR menyusun GBHN dikaitkan dengan fungsi dari Tap MPR, menurut A. Hamid Atamimi, Tap MPR berfungsi untuk mengatur

\footnotetext{
${ }^{13}$ Moh. Kusnardi dan Harmaily Ibrahim, Pengantar Hukum Tata Negara Indonesia, Jakarta, Pusat Studi Hukum Tata Negara, 1985, hlm. 46.

${ }_{14}^{14}$ Jimly Asshiddiqie, Format Kelembagaan Negara dan Pergeseran Kekuasaan dalam UUD 1945, Yogyakarta, FH UII Press, 2004, hlm. 39. hlm. 18.

${ }^{15}$ Joeniarto, Selayang Pandang Tentang Sumber-Sumber Hukum Tatanegara di Indonesia, Yogyakarta, Liberty, 1996,
} 
lebih lanjut hal-hal yang belum diatur dalam UUD, karena UUD mengatur hal-hal pokok saja. Pengaturan lebih lanjut tersebut untuk mengarahkan haluan negara yang dituangkan dalam GBHN ${ }^{16}$. Adapun menurut Rosjidi Ranggawidjaja, bahwa Tap MPR bersama-sama dengan Pembukaan dan Batang Tubuh UUD 1945 merupakan hukum positif aturan-aturan dasar yang dijabarkan dari Pancasila sebagai Norma Dasar (staatsfundamentalnom), tetapi jika ditelaah lebih lanjut materi Tap MPR mengandung norma hukum yang pada hakikatnya sama, namun setingkat lebih rendah dari norma hukum UUD $1945^{17}$.

Berdasarkan Pasal 102 Ketetapan MPR No. 1/MPR/1973 tentang Peraturan Tata Tertib MPR ditentukan tentang bentuk-bentuk Keputusan MPR: pertama, Ketetapan MPR yaitu putusan MPR yang mempunyai kekuatan hukum mengikat ke luar dan ke dalam Majelis; kedua, Keputusan MPR yaitu putusan MPR yang mempunyai kekuatan hukum mengikat ke dalam majelis. ${ }^{18}$

Sesuai dengan makna dan maksud dibentuknya Tap MPR, maka sebagai sumber hukum, Ketetapan MPR berisi antara lain: pertama, Ketetapan MPR yang memuat garis-garis besar dalam bidang legislatif dilaksanakan dengan undang-undang; kedua, Ketetapan MPR yang memuat GBHN dalam bidang ekskutif dilaksanakan dengan Keputusan Presiden. Hal ini berarti bahwa Ketetapan MPR di satu pihak dapat dilaksanakan dengan Keputusan Presiden. Sedangkan dari segi subtansi, Ketetapan MPR memiliki isi mengatur (regeling) dan merupakan keputusan (beschikking).

Keberadaan Tap MPR dalam hierarki aturan hukum di Indonesia, mengalami pasang surut sesuai dengan perkembangan ketatanegaraan Indonesia sendiri. Berdasarkan ketentuan Tap MPRS No. XX/MPRS/1966 dalam lampiran II-nya tentang Tata Urutan Peraturan Perundang-undangan menempatkan Tap MPR berada di bawah UUD 1945 dan di atas undang-undang. Dalam praktik, tata urut dan penamaan bentuk-bentuk peraturan tersebut tidak sepenuhnya diikuti. ${ }^{19}$ Kelemahan

${ }^{16}$ Maria Farida Indriati Soeprapto, Ilmu Perundang-undangan, dan Dasar-Dasar Pembentukannya (Disarikan dari Perkuliahan A. Hamid Atamimi), Kanisius, Jakarta, 1998, hlm. 41.

${ }^{17}$ Rosjidi Ranggawidjaja, Pengantar Ilmu Perundang-undangan Indonesia, Bandung, Mandar Maju, 1998, hlm. 41.

${ }^{18}$ Ketetapan MPR mempunyai kekuatan hukum mengikat ke luar dan ke dalam mengandung arti mengikat seluruh bangsa Indonesia, termasuk MPR sendiri sebagai lembaga beserta anggotanya, juga lembaga-lembaga yang lain. Sedangkan Keputusan MPR adalah bentuk keputusan MPR yang hanya dimaksudkan mengikat terhadap lingkungan MPR sendiri. Joeniarto, Selayang Pandang..., Op. Cit., hlm. 128.

${ }^{19}$ Ketidak konsistenan penggunaan di antaranya adalah: misalnya, apakah Ketetapan MPR itu termasuk peraturan atau bukan, karena isinya kadang--kadang sama dengan Keputusan Presiden yang hanya bersifat penetapan biasa. Sebagai contoh, Ketetapan MPR tentang pengangkatan Presiden dan Wakil Presiden, sifatnya sama dengan Keputusan Presiden yang ditetapkan untuk mengangkat atau memberhentikan pejabat sebagaimana disebut di atas. Lebih-lebih 
dan kekurangan dalam Ketetapan MPRS tersebut kemudian disempurnakan dengan Ketetapan MPR No. III/MPR/2000.

Meskipun Tap MPR No. III/MPR/2000 tersebut bersifat menyempurnakan, tetapi Ketetapan ini justru menimbulkan masalah lain, yaitu dengan menempatkan Perpu pada urutan di bawah undang-undang padahal seharusnya keduanya berada dalam derajat yang sama. Karena itu, diundangkan UU No. 10 Tahun 2004 dalam rangka mengganti fungsi dan mengadopsi materi Ketetapan No. III/MPR/2000.

Tabel 1

Perbandingan Kedudukan Tap MPR dalam Hierarki Peraturan Perundangundangan sebelum berlakunya UU No. 12 tahun 2011

\begin{tabular}{|c|c|c|c|}
\hline $\begin{array}{c}\text { Tap MPRS No. } \\
\text { XX/MPRS/1966 jo } \\
\text { Tap MPR No. V/ } \\
\text { MPR/1973 }\end{array}$ & $\begin{array}{c}\text { Tap MPR No. III/ } \\
\text { MPR/2000 }\end{array}$ & $\begin{array}{c}\text { UU } \\
\text { No. } 10 \text { Tahun } 2004\end{array}$ & Keterangan \\
\hline $\begin{array}{l}\text { UUD } \\
\text { Tap MPRS } \\
\text { UU/Perpu } \\
\text { PP } \\
\text { Keppres } \\
\text { Permen, dll }\end{array}$ & $\begin{array}{l}\text { UUD } \\
\text { Tap MPR/S } \\
\text { UU } \\
\text { Perpu } \\
\text { PP } \\
\text { Keppres } \\
\text { Perda }\end{array}$ & $\begin{array}{l}\text { UUD \& Perubahan UUD } \\
\text { UU/Perpu } \\
\text { PP } \\
\text { Perpres } \\
\text { Perda }\end{array}$ & $\begin{array}{l}\text { Kecuali UU No. } 10 \\
\text { Tahun } \\
\text { m e n e m p a t k a } \mathrm{n} \\
\text { kedudukan Tap MPR di } \\
\text { bawah UUD dan di atas } \\
\text { UU }\end{array}$ \\
\hline
\end{tabular}

Substansi mendasar dari ketentuan UU No. 10 Tahun 2004, bahwa UU ini telah meniadakan kedudukan Tap MPR sebagai salah satu bentuk peraturan perundangundangan. Hal ini dikarenakan, MPR hasil Pemilu 2004 telah mendasarkan diri kepada UUD 1945 pasca perubahan keempat tahun 2002, yang tidak lagi berwenang menetapkan GBHN dan ketetapan-ketetapan yang bersifat mengatur (regeling) dan mengikat untuk umum seperti sebelumnya. Satu-satunya produk hukum yang bersifat mengatur (regeling) yang termasuk lingkup kewenangan MPR adalah produk perubahan UUD yang dilakukan menurut ketentuan Pasal 37 UUD 1945.

lagi, menjelang berlangsungnya Sidang Umum MPR pada bulan Nopember 1999 yang lalu, karena adanya kebutuhan untuk melakukan perubahan terhadap pasal-pasal UUD 1945, tirnbul polemik mengenai bentuk hukum perubahan UUD itu sendiri. Jika perubahan itu dituangkan dalam bentuk Ketetapan MPR yang jelas ditentukan bahwa kedudukannya berada di bawah UUD, maka akan timbul kekacauan dalam sistematika berpikir menurut tata urut peraturan yang diatur menurut TAP MPRS No.XX/MPRS/1966 tersebut. Bagaimana mungkin UUD yang lebih tinggi diubah dengan peraturan yang lebih rendah. Karena itu, sebagai jalan keluar, telah disepakati bahwa bentuk hukum perubahan itu dinamakan 'Perubahan UUD' sebagai nomenklatur baru perundang-undangan Republik Indonesia selama lebih dari 30 tahun terakhir, harus dikaji ulang dan disempurnakan untuk kepentingan masa depan hokum dan sistem hukum nasional. 


\section{Rasio-yuridis Kedudukan Ketetapan MPR Masuk Kembali dalam Hierarki Peraturan Perundang-undangan}

Kedudukan Ketetapan MPR sebelum amandemen UUD 1945 ditemukan dalam Tap MPRS RI No. XX/MPRS/1966 tentang Tata Urutan Perundang-undangan yang kemudian dicabut dengan Tap MPR Nomor III/MPR/2000 tentang Sumber Hukum dan Tata Urutan Peraturan Perundang-undangan. Berdasarkan kedua ketetapan tersebut, menurut Rachmawati Puspitadewi, Tap MPRS/MPR berkedudukan di bawah UUD 1945 dan di atas UU yang memiliki makna, bahwa Tap MPR/MPRS akan mengatur secara langsung pokok-pokok aturan dalam UUD 1945, sekaligus berkaitan langsung dengan penetapan haluan negara. ${ }^{20}$

MPR secara yuridis berdasarkan UUD NRI 1945 diposisikan sebagai lembaga baru dan menjadi ada (exist) apabila menjalankan salah satu dari keempat kewenangan (bevoegdheden) yang diberikan (atribusi) oleh UUD NRI tersebut. ${ }^{21}$ Berdasarkan kenyataan demikian, pertanyaannya, apakah mungkin MPR dewasa ini masih berwenang mengadakan persidangan untuk membahas tentang pencabutan terhadap Tap MPR/S yang diwarisi masa lalu ataupun membuat Ketetapan MPR yang baru? Menurut Jimly Ashsiddiqie, “Secara konstitusional MPR tidak memiliki landasan untuk melakukan persidangan dalam rangka pembahasan tentang pencabutan terhadap Tap MPR/S yang diwarisi masa lalu ataupun membuat Ketetapan MPR yang baru. Sidang MPR hanya dapat dilaksanakan untuk menjalankan salah satu keempat kewenangan MPR". ${ }^{22}$

Meski demikian, berdasarkan Pasal I Aturan Tambahan UUD NRI 1945 memberikan tugas kepada MPR untuk melakukan peninjauan terhadap materi dan status hukum Tap MPRS/MPR. Ketentuan tersebut sekaligus sebagai upaya untuk menghindari ketidakpastian hukum dari Tap MPRS/MPR. Untuk melaksanakan amanat UUDNRI 1945, Forum Permusyawaratan Sidang-Sidang MPR 1999-2004 berhasil menyusun dan mengeluarkan Tap MPR RI No.I/MPR/2003 tentang Peninjauan terhadap Materi dan Status Hukum Tap MPRS dan Tap MPR 1960-2002.

${ }^{20}$ Rachmawati Puspitadewi, "Kedudukan dan Status Hukum Ketetapan MPRS dan Ketetapan MPR RI Setelah Perubahan Undang-Undang Dasar Republik Indonesia Tahun 1945”, Jurnal Hukum Pro Justitia, Vol. 25 No. 4, 2007, hlm. 325.

${ }^{21}$ Menurut ketentuan UUD NRI Pasal 3 juncto Pasal 8 juncto Pasal 37, bahwa 4 (empat) kewenangan MPR yang diberikan meliputi: (1) mengubah dan menetapkan UUD; (2) memberhentikan Presiden dan/atau Wakil Presiden; (3) memilih Presiden dan/atau Wakil Presiden untuk mengisi lowongan jabatan; dan (4) melantik Presiden dan/atau Wakil Presiden.

${ }^{22}$ Jimly Ashsiddiqie, Peribal Undang-Undang, Konstitusi Press, Jakarta, 2006, hlm. 163. 
Tap MPR RI No.I/MPR/2003 memuat pengelompokan Tap MPR/MPRS yang dikeluarkan 1960-2002. Pengelompokan tersebut dianggap penting karena masingmasing Tap MPR/MPRS yang dikeluarkan memiliki sifat, maksud, dan tujuan yang berbeda. Namun dilihat dari fungsinya, Tap MPR pada hakikatnya merupakan putusan yang bersifat penetapan yang bersifat individual, konkrit dan final, tidak lagi merupakan peraturan yang bersifat umum dan abstrak yang mengikat ke dalam dan ke luar. ${ }^{23}$

Pengelompokan tersebut menempatkan Tap MPR/MPRS ke dalam 5 (lima) kelompok: (1) Tap MPR/MPRS yang memuat aturan yang sekaligus memberi tugas kepada Presiden; (2) Tap MPR/MPRS yang bersifat penetapan (beschikking); (3) Tap MPR/MPRS yang bersifat mengatur ke dalam (intern regeling); (4) Tap MPR/MPRS yang bersifat deklaratif; (5) Tap MPR/MPRS yang bersifat rekomendasi dan perundang-undangan.

Selain pengelompokkan Tap MPR/MPRS tersebut, Tap MPR RI No.I/MPR/ 2003 juga mengklasifikasi Tap MPR/MPRS tahun 1960-2002 ke dalam 6 (enam) kelompok, yaitu: (1) Tap MPR/MPRS yang dicabut dan dinyatakan tidak berlaku meliputi 8 (delapan) ketetapan terdiri dari 1 (satu) Tap MPRS dan 7 (tujuh) Tap MPR. Misalnya, MPR RI No. XIII/MPR/1998 tentang Pembatasan Masa Jabatan Presiden dan wakil Presiden, karena telah diakomodir ke dalam Pasal 7 UUD NRI 1945; (2) Tap MPR/MPRS yang dinyatakan tetap berlaku dengan ketentuan tertentu meliputi 3 (tiga) ketetapan terdiri dari 1 (satu) Tap MPRS dan 2 (tujuh) Tap MPR. Misalnya, Tap MPRS RI No. XXV/MPRS/1968 tentang Pembubaran PKI, Pernyataan sebagai Organisasi Terlarang di Seluruh Wilayah Negara Republik Indonesia bagi PKI dan Larangan Setiap Kegiatan untuk menyebarkan atau Mengembangkan Faham atau Ajaran Komunisme/Marxisme-Leninisme, dengan alasan untuk menyelamatkan ideologi negara Pancasila; (3) Tap MPR yang tetap berlaku sampai dengan terbentuknya pemerintahan hasil pemilihan umum tahun 2004 meliputi 8 (delapan) ketetapan yaitu 8 (delapan) Tap MPR. Misalnya, Tap MPR RI No. VIII/ MPR/2000 tentang Penetapan Wakil Presiden Indonesia Megawati Soekarnoputri sebagai Presden Republik Indonesia. Tap ini dianggap bersifat enmalig dan dinyatakan telah selesai dilaksanakan; (4) Tap MPR/MPRS yang tetap berlaku sampai dengan terbentuknya undang-undang meliputi 11 (sebelas) ketetapan terdiri

${ }^{23}$ Setelah Tap MPR No. I/MPR/2003 diberlakukan, hanya Tap MPR No. I/MPR/2003 saja yang memiliki sifat ke luar. Lihat Rachmawati, Kedudukan dan Status..., Op. Cit., hlm. 354. 
dari 1 (satu) Tap MPRS dan 10 (sepuluh) Tap MPR. Misalnya, Tap MPR RI No. III/ MPR/2000 tentang Sumber Hukum dan Tata Urutan Peraturan Perundang-undangan yang dinyatakan tidak berlaku lagi akibat telah diundangkannya Undang-Undang RI Nomor 10 Tahun 2004, jenis dan hierarki peraturan perundang-undangan; (5) Tap MPR yang masih berlaku sampai dengan ditetapkannya Peraturan Tata Tertib yang baru oleh MPR RI hasil pemilihan umum 2004 meliputi 5 (lima) ketetapan yaitu 5 (lima) Tap MPR. Ke lima Tap MPR yang seluruhnya memiliki subtansi tentang aturan tata tertib MPR tersebut dinyatakan tidak berlaku lagi setelah dibentuk MPR RI hasil Pemilu 2004; (6) Tap MPR/MPRS yang tidak perlu dilakukan tindakan hukum lebih lanjut, baik karena bersifat einmalig (final), telah dicabut, maupun telah selesai dilaksanakan meliputi 104 (delapan) ketetapan terdiri dari 41 (empat puluh satu) Tap MPRS dan 63 (enam puluh tiga) Tap MPR.

Berdasarkan kenyataan demikian, maka keberadaan Tap MPR tetap menjadi relevan dalam tata urut perundang-undangan dan dijadikan rujukan bagi aturan hukum. Ketentuan ini secara yuridis dinyatakan dalam Penjelasan Umum UndangUndang Nomor 12 Tahun 2011 yang menyatakan “Undang-undang tentang Pembentukan Peraturan Perundang-undangan merupakan pelaksanaan dari perintah Pasal 22A UUD NRI 1945 ... . Namun, ruang lingkup materi muatan UndangUndang ini diperluas tidak saja Undang-Undang tetapi mencakup pula Peraturan Perundang-undangan lainnya, selain UUD NRI 1945 dan Ketetapan Majelis Permusyaratan Rakyat". Selanjutnya dinyatakan bahwa undang-undang ini merupakan penyempurnaan terhadap kelemahan-kelemahan dalam UndangUndang Nomor 10 Tahun 2004, yaitu antara lain: a) materi dari Undang-Undang Nomor 10 Tahun 2004 banyak yang menimbulkan kerancuan atau multitafsir sehingga tidak memberikan suatu kepastian hukum; b) ...; c) terdapat materi baru yang perlu diatur sesuai dengan perkembangan atau kebutuhan hukum dalam Pembentukan Peraturan Perundang-undangan; dan e)... .

Dan sebagai penyempurnaan terhadap undang-undang sebelumnya, terdapat materi muatan baru yang ditambahkan dalam Undang-Undang ini yaitu antara lain: a) penambahan Ketetapan Majelis Permusyawaratan Rakyat sebagai salah satu jenis peraturan perundang-undangan dan hierarkinya ditempatkan setelah UndangUndang Dasar Negara Republik Indonesia Tahun 1945, b)... . Dengan ketentuan hukum tersebut maka, sejak 12 Agustus 2011 Ketetapan MPR masuk kembali dalam hierarki peraturan perundang-undangan . 


\section{Kedudukan dan Status Hukum Ketetapan MPR Berdasarkan Undang-Undang} Nomor 12 Tahun 2011 tentang Pembentukan Peraturan Perundang-Undangan

Perubahan UUD 1945 telah mengubah kedudukan dan status hukum Tap MPR. Perubahan tersebut akibat dari pergeseran kedudukan $\mathrm{MPR}^{24}$ dan perubahan fungsi serta wewenang $\mathrm{MPR}^{25}$. Dengan terjadinya pergeseran kedudukan dan perubahan fungsi serta wewenang MPR, berimplikasi pada 2 (dua) hal: Pertama, produk peraturan yang dibuat MPR setelah perubahan UUD 1945 hanya meliputi (1) penetapan atau perubahan UUD; dan (2) ketetapan MPR dan keputusan MPR, tanpa GBHN. ${ }^{26} \mathrm{Kedua}$, perubahan terhadap sifat dari produk MPR, terutama yang berkaitan dengan Tap MPR yang semula bersifat mengikat ke luar dan ke dalam, menjadi hanya bersifat mengikat ke dalam saja.

Undang-Undang Nomor 10 Tahun 2004, merupakan produk hukum setelah perubahan UUD 1945 sekaligus sebagai salah satu aturan hukum operasional dari UUD NRI 1945. Hal yang perlu dicermati bahwa dalam Undang-Undang Nomor 10 Tahun 2004 tidak dikenal lagi adanya Tap MPR dalam hierarki peraturan perundangundangan. Tetapi ironisnya, masih ada beberapa Tap MPR yang tetap diberlakukan meskipun kedudukan dan status hukumnya telah dianulir menurut Undang-Undang Nomor 10 Tahun 2004. Misalnya, Tap MPR RI No. VI/MPR/2000 tentang Pemisahan TNI dan POLRI. Walaupun ketentuan ini telah diakomodasi dalam Undang-Undang Nomor 2 tahun 2002 tentang Kepolisian Negara RI, Undang-Undang Nomor 3 tahun 2002 tentang Pertahanan Negara dan Undang-Undang Nomor 34 tentang Tentara Nasional Indonesia, tetapi Tap MPR RI No. VI/MPR/2000 tersebut dinyatakan tetap berlaku karena peraturan kerjasama dan saling membantu antara TNI dan POLRI masih perlu diatur lebih lanjut oleh Undang-Undang. ${ }^{27}$ Berdasarkan kenyataan demikian terjadi permasalahan hukum terhadap keberadaan Tap MPR tersebut.

${ }^{24}$ Sesuai dengan perubahan pertama UUD 1945, kedudukan MPR yang semula sebagai Lembaga Tertinggi Negara bergeser menjadi Lembaga Tinggi Negara sejajar dengan lembaga tinggi negara lainnya seperti DPR, DPD, Presiden, MA, MK dan BPK.

${ }^{25}$ Berdasarkan ketentuan Pasal 3 UUD NRI 1945, kewenangan yang diberikan (atribusi) UUD kepada MPR adalah: (1) wewenang mengubah dan menetapkan UUD; (2) wewenang melantik Presiden dan/atau Wakil Presdien; dan (3) wewenang memberhentikan Presiden dan/atau Wakil Presiden.

${ }^{26}$ Berdasarkan Keputusan MPR RI No. VII/MPR/2004, bentuk dari putusan MPR terdiri dari: (1) putusan tentang perubahan dan penetapan Undang-Undang Dasar; dan (2) Ketetapan dan Keputusan.

${ }^{27}$ Tap-Tap lain yang tergolong masih diberlakukan adalah Tap MPRS RI No. XXIX/MPRS/1966 tentang Pengangkatan Pahlawan Ampera, Tap MPRS RI No. XI/MPR/1998 tentang Penyelenggaraan Negara yang Bersih dan Bebas KKN, Tap MPR RI No. XV/MPR/1998 tentang Penyelenggaraan Otonomi Daerah, Pengaturan, Pembagian dan Pemanfaatan Sumber Daya Nasional yang Berkeadilan. 
Menyadari permasalahan berkaitan dengan keberadaan Tap MPR, UndangUndang Nomor 12 Tahun 2011 telah meletakkan kembali Ketetapan MPR (S) dalam tata urut peraturan perundangan Indonesia. Secara hierarki tata urut yang baru menurut undang-undang ini adalah sebagai berikut: (1) UUD Negara Republik Indonesia 1945; (2) Ketetapan MPR; (3) Undang-Undang dan Peraturan Pemerintah Pengganti UU atau Perpu; (4) Peraturan Pemerintah (PP); (5) Peraturan Presiden; (6) Perda Provinsi; dan (7) Perda Kabupaten/Kota. Menurut Hajriyanto Y. Thohari, bahwa: dengan masuknya kembali Tap MPR dalam salah satu hierarki peraturan perundanganundangan ini memberikan arti bahwa Ketetapan MPR kembali didudukkan dalam posisinya yang benar dalam sistem hukum di Indonesia. Implikasinya sungguh sangat besar dan signifikan: Tap MPR kembali menjadi sumber hukum formal dan material. Tap MPR harus kembali menjadi rujukan atau salah satu rujukan selain UUD 1945 bukan hanya dalam pembentukan perundang-undangan di negeri ini, melainkan juga dalam pembentukan kebijakan-kebijakan publik lainnya. DPR dan Pemerintah (Presiden) mutlak harus memperhatikan Tap-Tap MPR yang masih berlaku, bahkan merujuk kepadanya dalam pembentukan undang-undang dan peraturan perundang-undangan di bawahnya ${ }^{28}$.

Berdasarkan kenyataan tersebut pertanyaan yang muncul adalah: pertama, samakah kedudukan dan status hukum Ketetapan MPR yang dibentuk sebelum perubahan UUD 1945 dengan yang Ketetapan MPR yang dibentuk setelah perubahan UUD 1945? Pertanyaan ini urgen dimunculkan mengingat terdapat perbedaan kedudukan dan status hukum MPR yang dibentuk sebelum perubahan UUD 1945 dan MPR yang dibentuk setelah perubahan UUD 1945. MPR sebelum perubahan UUD 1945 berstatus sebagai Lembaga Tertinggi Negara (Supreme Body), sedangkan MPR setelah perubahan UUD 1945 berstatus sebagai Lembaga Tinggi Negara. Memperhatikan kedudukan yang demikian tentu memberikan implikasi yang berbeda terhadap kedudukan dan status hukum Tap MPR yang dibentuk sebelum perubahan UUD 1945 dan sesudah perubahan UUD 1945. Kedua, bagaimana mekanisme pengujian (judicial review) Tap MPR tersebut dan bagaimana mekanisme pengujian (judicial review) aturan hukum di bawahnya yang dianggap bertentangan dengan Tap MPR.

${ }^{28}$ Hajriyanto Y. Thohari, “Eksistensi Ketetapan MPR Pasca UU NO. 12 Tahun 2011”, Makalah dipresentasikan pada Acara Pers Gathering Wartawan Parlemen, tanggal 11-13 November di Pangkal Pinang, Propinsi Babel, hlm. 3-4. 


\section{Kedudukan, Status dan Kekuatan Hukum Tap MPR}

Undang-Undang Nomor 12 Tahun 2011 telah menempatkan Tap MPR secara hierarki berada di bawah UUD dan di atas UU, tetapi masalah yang masih timbul dengan diberlakukannya UU 12 Tahun 2011 adalah mengenai kekuatan hukum Tap MPR - yaitu apakah dengan hierarki demikian Ketetapan MPR memiliki derajat di bawah UUD dan di atas UU ataukah Ketetapan MPR sederajat dengan UUD ataukah dengan UU? Hal ini perlu dianalisis mengingat MPR tidak lagi berwenang untuk membahas ketetapan-ketetapan yang telah dibuatnya sendiri di masa lalu. Oleh sebab itu, lembaga mana yang dianggap berwenang membahasnya tergantung kejelasan mengenai status hukum Tap MPR/S itu sendiri, apakah disederajatkan dengan UUD, di bawah UUD ataukah disederajatkan dengan UU?

Sebelum membahas mengenai derajat Tap MPR, terlebih dahulu perlu dipahami Tap MPR yang manakah yang dimaksud dalam UU No. 12 Tahun 2011 tersebut. Pasal 7 ayat (1) UU No. 12 Tahun 2011 menjelaskan bahwa: Ketetapan Majelis Permusyawaratan Rakyat adalah Ketetapan Majelis Permusyawaratan Rakyat Sementara dan Ketetapan Majelis Permusyawaratan Rakyat yang masih berlaku sebagaimana dimaksud dalam Pasal 2 dan Pasal 4 Ketetapan MPR RI No. I/MPR/2003 tentang Peninjauan terhadap Materi dan Status Hukum Ketetapan Majelis Permusyawaratan Rakyat Sementara dan Ketetapan Majelis Permusyawaratan Rakyat 1960 sampai dengan 2002, 7 Agustus 2003.

Berdasarkan ketentuan Pasal 7 ayat (1) Undang-Undang Nomor 12 Tahun 2011 tersebut dapat disimpulkan bahwa meskipun Undang-Undang Nomor 12 Tahun 2011 mengkategorikan Tap MPR termasuk bagian dari jenis dan hierarki peraturan perundang-undangan, namun tidak berarti MPR masih mempunyai wewenang untuk membentuk Tap MPR yang baru pasca perubahan UUD 1945. Hal ini bisa dipahami, karena yang dimaksud dengan Tap MPR dalam Pasal 7 ayat (1) UndangUndang Nomor 12 Tahun 2011 tersebut hanya terhadap Tap MPR yang dinyatakan masih berlaku berdasarkan Tap No. I/MPR/2003. Dengan demikian, ketentuan Pasal 7 ayat (1) Undang-Undang Nomor 12 Tahun 2011 hanya untuk mengakomodasi Tap MPR yang masih dinyatakan berlaku dan bersifat regeling.

Berkaitan dengan derajat hukum dari Tap MPR, terdapat berbagai wacana yang berkembang. Jika dibaca dari segi hierarki - derajat kekuatan hukum Tap MPR berada di bawah UUD dan di atas UU. Tetapi hal ini tentu berbeda jika dipandang dari segi bentuknya dan lembaga yang berwenang menetapkannya, Tap MPR/MPRS 
bukanlah UU. Artinya Tap MPR dianggap lebih tinggi dari UU dan karena itu setara dengan UUD, karena beberapa alasan: pertama, secara historis sampai dengan pelaksanaan Sidang MPR tahun 2003, kedudukan Tap MPR lebih tinggi daripada kedudukan UU. Kedua, dari segi bentuknya, Tap MPR bukan berbentuk UU, sehingga tidak dapat disetarakan dengan UU. Ketiga, dari segi pembentuk atau lembaga negara yang menetapkannya, Tap MPR tidak ditetapkan oleh pembentuk UU, yaitu DPR bersama-sama Presiden, melainkan oleh MPR/S.

Berdasarkan hal tersebut, maka pemilihan derajat kekuatan hukum Tap MPR hanya ada 2 (dua) kemungkinan yaitu sederajat dengan UUD atau sederajat dengan UU. Meski demikian berdasarkan Tap No. I/MPR/2003, MPR menyatakan bahwa Tap MPR/S yang tetap berlaku - masih tetap berlaku sampai terbentuknya undangundang yang mengatur materi ketetapan-ketetapannya. Artinya, Tap MPR/S itu ditundukkan derajatnya oleh MPR sendiri, sehingga dapat diubah oleh atau dengan undang-undang. Dengan demikian harus disimpulkan bahwa MPR sendiri telah menundukkan kedudukan dan status hukum Tap MPR yang pernah dibuatnya setingkat dengan undang-undang sehingga untuk selanjutnya Tap MPR yang termaktub dalam Undang-Undang Nomor 12 Tahun 2011 harus dipandang sederajat dengan undang-undang atau lebih tinggi sedikit daripada undang-undang.

Permasalahan lain berkaitan dengan status dan kekuatan hukum Tap MPR adalah tentang pengujian Tap MPR, karena meskipun MPR tidak akan membentuk Tap MPR lagi yang mengatur secara umum (regeling), akan tetapi tidak akan menutup kemungkinan bahwa akan terdapat permohonan pengujian Tap MPR yang masih dinyatakan berlaku berdasarkan Tap MPR Nomor 1/MPR/2003 oleh warga negara yang mempunyai legal standing dimana hak-hak konstitusionalnya dilanggar oleh berlakunya Tap MPR yang masih berlaku tersebut. Pertanyaannya adalah lembaga mana yang memiliki wewenang untuk melakukan pengujian (review) terhadap Tap MPR tersebut?

Untuk hal ini tentunya perlu kiranya memahami kedudukan Tap MPR setelah berlakunya Undang-Undang Nomor 12 Tahun 2011. Berdasarkan hierarki UndangUndang Nomor 12 Tahun 2011 menempatkan Tap MPR di bawah UUD tetapi di atas UU. Jika digunakan anasir hierarki, maka kedudukan Tap MPR secara hierarki lebih rendah daripada UUD, tetapi lebih tinggi dari UU. Apakah dengan demikian juga berarti mekanisme pengujian (review), juga mengikuti mekanisme sebagaimana pengujian UU di bawah UUD yang dilakukan oleh MK? 
Pengujian terhadap materi aturan hukum semisal UU pada dasarnya dapat dilakukan melalui 3 (tiga) cara, yaitu: judicial review, constitutional review dan legislative review. Judicial review dan constitutional review suatu mekanisme pengujian UU yang dilakukan oleh MK, sedangkan legislative review adalah mekanisme pengujian UU yang dilakukan lembaga pembuat UU tersebut dalam hal ini DPR atau Presiden ataupun keduanya. Jika DPR dan Presiden diperkenankan mencabut Tap MPR berdasarkan ketentuan perundangan-undangan, maka tidak ada alasan bahwa MK tidak boleh melaksanakan pengujian. Suatu konsekuensi logis, mengingat mekanisme judicial review dan constitutional review merupakan upaya konstitusional yang disediakan oleh UUD 1945 apabila mekanisme legislative review tidak atau belum diadakan, sedangkan ketentuan yang terkandung di dalam suatu produk peraturan telah menimbulkan kerugian konstitusonal bagi warga negara atau subyek hukum yang dilindungi hak dan kewenangan konstitusionalnya oleh UUD 1945.

Hal ini cukup dipahami, karena jika terjadi pelanggaran hak-hak konstitusional yang dinilai oleh berlakunya Tap MPR yang dinyatakan masih berlaku maka akan banyak merugikan masyarakat sebagai warga negara, sehingga apabila pengujian Tap MPR itu harus menunggu sidang tahunan MPR, maka hal itu akan membutuhkan waktu dan proses yang lama dan akan semakin menambah volume kerugian bagi masyarakat.

Bagaimanakah seharusnya pengujian terhadap Tap MPR dan pengujian aturan hukum di bawah Tap MPR? Dewasa ini hanya dikenal 2 (dua) jenis mekanisme pengujian terhadap aturan hukum (judicial review). Pertama, terhadap undang-undang yang dianggap bertentangan dengan UUD pengujian dilakukan oleh Mahkamah Konstitusi (MK). Kedua, pengujian terhadap aturan hukum di bawah undang-undang dilakukan oleh Mahkamah Konstitusi (MK). Pertanyaannya, bagaimana mekanisme pengujian terhadap UU yang dianggap bertentangan dengan Tap MPR dan bagaimana mekanisme pengujian terhadap aturan hukum di bawah UU yang dianggap bertentangan dengan Tap MPR.

Kedudukan UU dalam UU No. 12 Tahun 2011 secara normatif berada di bawah Tap MPR, namun secara teoritis masih diperdebatkan. Jika dilihat posisi MPR dalam UUD 1945 sebelum perubahan, yang mana MPR merupakan lembaga tertinggi negara, maka Tap MPR posisinya memang lebih tinggi dari UU, akan tetapi jika dilihat posisi MPR setelah amandemen UUD 1945, posisi MPR setingkat dan sederajat dengan DPR dan Presiden, yang membuat UU, maka Tap MPR bisa 
dikatakan setingkat dengan UU. Tap MPR yang dimaksud dalam UU No. 12 Tahun 2011 adalah Tap MPR yang ditetapkan pada saat MPR masih menjadi lembaga tertinggi negara, maka hierarkinya tentu lebih tinggi dari UU yang dibuat oleh DPR bersama Presiden yang hanya lembaga tinggi negara.

Tap MPR/S sebelum amandemen UUD 1945 merupakan aturan hukum dasar di samping UUD 1945 yang memuat norma dasar dan bersifat regeling, posisinya jelas berada di atas UU yang lebih teknis. Setelah amandemen UUD 1945 posisi Tap MPR tidak lagi menjadi aturan hukum dasar, dan UUD 1945 adalah aturan hukum dasar tunggal, serta bersifat beshicking bagi administrasi internal MPR saja.

Berdasarkan lembaga yang membuatnya, Tap MPR secara teoritis setingkat dengan UUD 1945, karena dibuat oleh MPR, yang membedakannya adalah pertama, MPR mengubah dan menetapkan UUD 1945 karena fungsinya sebagai konstituante, sedangkan dalam menetapkan Tap MPR fungsinya hanya sebatas legislasi biasa. Kedua, prosedur amandeman UUD 1945 begitu rumit, sedangkan perubahan Tap MPR tidak begitu sulit, yakni sama seperti UU. Oleh karena itu Tap MPR secara hierarki berada di bawah UUD 1945.

Karena sama-sama ditetapkan oleh MPR, maka dalam judicial review UU terhadap Tap MPR diberikan kewenangan pengujiannya kepada Mahkamah Konstitusi. Kewenangan ini selain karena alasan UUD 1945 dan Tap MPR samasama ditetapkan oleh MPR, tetapi juga untuk mengisi kekosongan hukum mengenai pengujian UU terhadap Tap MPR. Dalam hal ini keadilan substantif lebih diutamakan dibandingkan dengan kepastian hukum.

Analogi dengan ketentuan di atas, maka sebaliknya jika aturan hukum di bawah UU dianggap bertentangan dengan Tap MPR maka mekanisme judicial review dilakukan oleh Mahkamah Agung, sebagaimana mekanisme judicial review yang selama ini dilakukan terhadap aturan hukum yang berada di bawah UU.

\section{Penutup}

Masuknya kembali Ketetapan MPR/MPRS dalam hierarki peraturan perundang-undangan merupakan conditio sine quanon. Secara rasiologis, berdasarkan ketentuan Tap MPR RI No.I/MPR/2003 hingga saat ini masih terdapat Tap MPR/ MPRS yang dinyatakan masih berlaku dan relevan, sehingga keberadaannya tetap dipertahankan. Sedangkan secara yuridis berdasarkan UU No. 12 Tahun 2011 bahwa 
ruang lingkup materi muatan Undang-Undang ini diperluas tidak saja UU tetapi mencakup pula peraturan perundang-undangan lainnya, selain UUD NRI 1945 dan Ketetapan Majelis Permusyaratan Rakyat.

Perubahan kedudukan MPR telah membawa perubahan pula terhadap kedudukan dan status hukum produk hukum yang dihasilkan oleh MPR yaitu Tap MPR. Tap MPR yang baru (Tap MPR setelah perubahan UUD 1945) tidak lagi memiliki kekuatan hukum sebagai regeling yang memiliki daya ikat ke luar maupun ke dalam lembaga tetapi hanya sebatas beschikking yang memiliki kekuatan hukum mengikat ke dalam lembaga MPR. ${ }^{29}$

Berkaitan dengan Tap MPR hasil produk MPR sebelum perubahan UUD 1945, memiliki kekuatan hukum sebagai regeling sesuai dengan kedudukan MPR pada saat itu sebagai Lembaga Tertinggi Negara. Berdasarkan UU No. 12 Tahun 2011 menempatkan kedudukan Tap MPR berada di bawah UUD dan di atas UU. Meski demikian dari segi kekuatan hukum Tap MPR masih menimbulkan permasalahan. Artinya apakah derajat kekuatan hukum Tap MPR setara dengan UUD atau sederajat dengan UU. Hal ini berimplikasi terhadap 2 (dua) hal: Pertama, mekanisme perubahan: (1), jika Tap MPR sederajat dengan UUD, maka Tap MPR tidak dapat dicabut ataupun diubah kecuali melalui mekanisme perubahan UUD sebagaimana diatur dalam Pasal 37 UUD NRI 1945. Kedua, apabila derajat Tap MPR setara dengan UU, maka Tap MPR dapat dicabut dan diubah oleh DPR bersama-sama Presiden, yaitu dengan UU.

\section{Daftar Pustaka}

Asshiddiqie, Jimly, Format Kelembagaan Negara dan Pergeseran Kekuasaan dalam UUD 1945, FH UII Press, Yogyakarta, 2004.

Perihal Undang-Undang, Konstitusi Press, Jakarta, 2006.

, Jimly, "Tata Urut Perundang-Undangan dan Problema Peraturan Daerah", www.google.com/Reformasi Peraturan PerundangUndangan/htlm. Diakses pada 06 April 2001.

Boy Yendra Tamim, “Tap MPR Kembali Masuk dalam Tata Urutan Peraturan Perundang-undangan", http:/ / boyyendratamin.blogspot.com/TAP\%20 MPR\%20Kembali\%20Masuk\%20Dalam\%20Tata\%20Urutan\%20Peraturan\%20 Perundang-Undangan\%20-\%20Dunia\%20Hukum.htm, diakses 20 Juli 2012.

${ }^{29}$ MPR sekarang dan mendatang masih tetap dapat mengeliatkan produk hukum berupa Peraturan Tata Tertib MPR dan produk hukum Ketetapan MPR dalam pengertian yang berbeda dengan sebelumnya. 
Chotidjah, Nurul, "Dinamika Implementasi Kewenangan Mahkamah Agung dan Komisi Yudisial Setelah Amandemen Undang-Undang Dasar 1945" Jurnal Ilmu Hukum Litigasi Volume IX No. 3, 2008.

Farida Indriati Soeprapto, Maria, Ilmu Perundang-undangan, dan Dasar-Dasar Pembentukannya (Disarikan dari Perkuliahan A. Hamid Atamimi), Jakarta, Kanisius, 1998.

Hadjon, Philipus M, “Eksistensi, Kedudukan, dan Fungsi MPR sebagai Lembaga Negara dalam Sistem Ketatanegaraan Republik Indonesia", dalam Departemen Hukum Tatanegara Fak. Hukum Universitas Airlangga, 2008. Dinamika Perkembangan Hukum Tata Negara dan Hukum Lingkungan, Airlangga University Press, Surabaya. 2008.

Hajriyanto Y. Thohari, 2011, “Eksistensi Ketetapan MPR Pasca UU No. 12 Tahun 2011", Makalah dipresentasikan pada acara Pers Gathering Wartawan Parlemen, tanggal 11-13 November 2011 di Pangkal Pinang, Propinsi Babel

Heryanto, Bambang, "Refleksi Politik Hukum Pelanggaran Hak Asasi Manusia di Indonesia", Yuridika, Vol. 17 No. 4, 2002.

Hutchinson, Terry, Researching and Writing in Law, Lawbook. Co. Pyrmont-NSWSydney, Sydney, 2002.

Indrayana, Denny, “Negara Hukum Indonesia Pasca Soeharto: Transisi Menuju Demokrasi vs Korupsi", dalam Jurnal Konstitusi, Vol. 1 No. 1, 2004.

Joeniarto, Selayang Pandang tentang Sumber-Sumber Hukum Tata Negara di Indonesia, Liberty, Yogyakarta. 1991.

Kusnardi dan Harmaily Ibrahim, Moh., Pengantar Hukum Tata Negara Indonesia, Pusat Studi Hukum Tata Negara, Jakarta, 1985.

Laksono, R. Agung, “Dewan Perwakilan Rakyat Republik Indonersia Pasca Perubahan Undang-Undang Dasar Negara Republik Indonesia Tahun 1945", Jurnal Majelis Vol. 1 No.1, 2009.

M. Hadjon, Philipus, “Analisis Terhadap UU No. 10 Tahun 2004 Tentang Pembentukan Peraturan Perundang-Undangan", Makalah disampaikan pada Seminar.

Magnar, Kuntana, “Kedudukan, Tugas, Fungsi dan Kewenangan Lembaga-Lembaga Negara di Indonesia" dalam Jurnal Ilmu Hukum Litigasi, Vol. 1 No. 2, 2007.

Mahmud Marzuki, Peter, "Jurisprudence As Sui Generis Discipline”, Jurnal Hukum Yuridika Vol. XVII No. 4, 2002.

Martin Punggar, Chemi, "Status dan Kedudukan MPR Pasca Amandemen Ke-IV UUD 1945",dalam http:/ / htnfhunsri2009.wordpress.com/ STATUS\%20DAN\%20KEDUDUKAN\%20MPR\%20PASCA\%20AMANDEMEN\%20KEIV\%20UUD\%201945\%20«.htm, diakses 25 Juli 2012

Pigome, Martha, “Implementasi Prinsip Demokrasi dan Nomokrasi dalam Struktur Ketatanegaraan RI Pasca Amandemen UUD 1945" dalam Jurnal Dinamika Hukum Vol. 11 No. 2, 2011. 
Poetra Adi Soerjo, Tth, “Implementasi Tap MPR No. IX Tahun 2001”, dalam http:/ /hukum.kompasiana.com/2012/05/13/implementasi-tap-mpr-no-ixtahun-2001/diakses 6 Agustus 2012

Puspitadewi, Rachmani, "Kedudukan dan Status Hukum Ketetapan MPRS dan Ketetapan MPR RI Setelah Perubahan Undang-Undang Dasar Republik Indonesia Tahun 1945", Jurnal Hukum Pro Justitia, Vol. 25 No. 4, 2007.

Radjab, Dasril, Hukum Tatanegara Indonesia, Rineka Cipta, Jakarta, 1994.

Ranggawidjaja, Rosjidi, Pengantar Ilmu Perundang-undangan Indonesia, Mandar Maju, Bandung, 1998.

Saleh, K. Wantjik, Perkembangan Perundang-Undangan di Indonesia, Rineka Cipta, Jakarta, 1996.

Saleh, Moh., “Wewenang Pengujian Ketetapan Majelis Permusyawaratan rakyat Pasca Pemberlakuan Undang-Undang Nomor 12 Tahun 2011 Tentang Pembentukan Peraturan Perundang-undangan",

Salman Tabir. Tth. "Pengujian Undang-Undang Terhadap Tap MPR", dalam http:// salmantabir.wordpress.com/2011/11/27/pengujian-undang-undang-terhadap-tap-mprs/ htm. diakses 1 Agustus 2012.

Sumantri, Sri, “Kedudukan, Wewenang dan Fungsi Komisi Yudisial dalam Sistem Ketatanegaraan RI", dalam Bunga Rampai Refleksi Satu Tahun Komisi Yudisial Republik Indonesia, Komisi Yudisial RI, Jakarta.

Triwulan Tutik, Titik, Konstruksi Hukum Tata Negara Indonesia Pasca Amandemen UUD 1945, Kencana Prenada Media Group, Jakarta, 2010.

Widawati, Ayudya, “Seleksi Hakim Agung 2008, Mencari Hakim Agung yang Profesional, Berkualitas, Berintegrasi, Akuntabel dan Transparan dalam Rangka Menegakkan Prinsip Check and Balances Kekuasaan Kehakiman di Indonesia", Teropong, Vol. VII No. 1, 2008.

\section{UUD NRI 1945}

Ketetapan MPR RI Nomor 1/MPR/2003 tentang Peninjauan Terhadap Materi dan Status Hukum Tap MPR/MPRS RI dari 1960-2002

UU No. 10 Tahun 2004 tentang Pembentukan Peraruran Perundang-undangan.

UU No. 12 Tahun 2011 tentang Peraturan Perundang-Undangan. 